\title{
GENERAL SCIENTIFIC APPROACHES TO DEFINING THE FUNCTIONS OF THE CONSTITUTIONAL MECHANISM OF STATE POWER
}

\author{
Volodymyr Shatilo, \\ Head of the Law Department of Kyiv National Linguistic University \\ Doctor of Juridical Science, Associate professor, \\ Honored Jurist of Ukraine, \\ orcid.org/0000-0003-3274-4744 \\ vash13@ukr.net
}

\section{Summary}

The purpose of this work is to define the concept of functions of the state power constitutional mechanism through the study of doctrinal positions of function in various branches of social sciences.

Methodology for the functions' study of the state power constitutional mechanism consists of the methods of cognition, discovered and developed by philosophy, history, sociology, theory of law and state, specialized legal sciences and approved by legal practice. Thus, the role of the historical method in the analysis of the functions of the constitutional mechanism of state power, in addition to explaining the nature of origin and development, is to ensure a systematic study of the evolution of this category. The semantic method was used to clarify the meaning of the term "function", its scientific and practical meaning, the possibility of using it in constitutional law to refer to such legal categories as "constitutional mechanism of state power". The comparative method was applied to reveal the general in such terms as "functions", "goals" and "tasks".

The results of the study show that the function is a kind of "a pattern", "a standard", "an ideal model" of the system's work, in particular, of the constitutional mechanism of state power, and therefore, it must be, on the one hand, differentiated from the goals and tasks that face the system, and on the other hand - from the real, actual activity of its institutions (competences). When determining the functions of the constitutional mechanism of state power, it must be assumed that, firstly, the functions are the directions of influence of a certain socially significant phenomenon or circumstance on certain legal relations, and secondly, the functions are the activity of certain subjects of the constitutional mechanism of state power within the limits of the powers specified in the Constitution and laws; thirdly, functions reflect the essence of the phenomenon, its purpose and patterns of development. The theory of functions of the constitutional mechanism of state power should proceed from the social purpose of the state, its tasks and goals, the legislation of Ukraine, as well as the experience of practical activity of the state apparatus and the achievement of scientific opinion in the field of constitutional law and a number of theoretical and applied legal sciences. Actually the system of functions of the state determines the need to study the functions of the constitutional mechanism of state power, but if the functions of the state are the directions of influence on public relations, then the functions of the constitutional mechanism of state power are the directions of the state functions within the competence of individual institutions that make up the structure of the constitutional mechanism of the state power.

On the basis of this research, the author comes to the conclusion that the functions of the constitutional mechanism of state power should be defined as the directions of activity of the subjects of the constitutional mechanism of state power within the competence defined in the Constitution and laws aimed at achieving the goals and tasks of the state.

Key words: function; mechanism of state power; functions of the state; goals; tasks; activities of the state. 


\section{Introduction}

Contemporary understanding of functions is an important component of the study of the constitutional mechanism of state power. It is obvious that functionality is the most essential aspect of any organization (Setrov, 1972), because in the general theory of systems of function they are one of the main characteristics of the essence of the object under consideration (Afanasiev, 1981). Namely in the functions the essential properties of the constitutional mechanism of state power as the centralizing power of society and the macro-regulator of social relations are reflected. It expresses the will of the vast majority of the population, while being realized through a legal system that exerts significant regulatory and ordering influence on political, economic and social life of society, social groups and individuals.

An analysis of the source base of the study revealed the existence of a significant scientific heritage, based on the work of both classics and modern researchers of problems of state power and statehood not only in the field of law, but also of political science, philosophy, history, sociology, as well as practitioners who have been working on this issue in different times. The first most complete and consistent conceptual justification and expression of the idea of state power and the evolution of statehood were presented in the works of such bright thinkers as Shang Yang, Confucius, Aristotle, Democritus, Plato, Cicero, Socrates, supplemented by such representatives of the Renaissance, like N. Machiavelli, J.-J. Rousseau, T. Hobbes, J. Locke, I. Kant, J.-G. Fichte, G. Hegel, T. Campanella, C.-L. Montesquieu, T. More, A. Schopenhauer, V. Pareto, R. Michels, F. Nietzsche, G. Mosca, G. Jellinek, R. Dahl, L. Duguit, K. Marx, F. Engels, V. Lenin, M. Weber, B. Russell, T. Parsons, M. Foucault and others, whose theories and conceptual approaches were later formed into separate specific scientific schools and research approaches.

So, since the 50s of the twentieth century the amount of literature on state power and the institutions of statehood is growing sharply. Substantial contributions to the development of concepts of power have been made by R. Berstedt, P. Blau, D. Cartwright, S. Clegg, N. Luhmann, F. Oppenheimer, D. Wrong and others. The problems of organization and functioning of state power and its institutions, its unity and division are presented in the works of many authoritative domestic researchers of the early twentieth century and scientists of pre-revolutionary Russia, in particular A. S. Alekseev, O. O. Alekseev, V. M. Hessen, V. F. Deriuzhynskyi, A. I. Yelistratov, V. V. Ivanovskyi, I. A. Ilin, M. M. Kovalevskyi, F. F. Kokoshkin, M. M. Korkunov, S. A. Kotliarevskyi, M. I. Lazarevskyi, S. A. Muromtsev, M. I. Palienko, I. T. Tarasov, B. M. Chycherin, G. F. Shershenevych, A. S. Yashchenko and others. Soviet science has also accumulated considerable conceptual experience in the study of state power and problems of statehood. In particular, it is possible to distinguish the works of R. P. Aleksiuk, V. M. Amelin, M. Yo. Baitin, M. M. Keizerov, A. J. Kim, V. G. Lediaiev, O. O. Luzan, V. B. Pastukhov, M. M. Stepanov, Yu. O. Tykhomyrov, V. L. Usachev, Ye. I. Farber, V. V. Tsvietkov, V. Ye. Chyrkin, L. P. Yuzkov and others.

In the last decade, interest to the study of problems of state power, its types, forms, functions and mechanism of implementation in the context of modern transformation processes has increased significantly in both domestic and foreign science. In particular, crucial are the achievements of such national scientists as V. B. Averianov, O. F. Andriiko, V. D. Babkin, M. O. Baimuratov, V. P. Horbatenko, A. P. Zaiets, O. V. Zaichuk, A. A. Kovalenko, O. L. Kopylenko, L. T. Kryvenko, N. M. Onishchenko, M. P. Orzikh, O. V. Petryshyn, V. F. Pogorilko, A. O. Selivanov, V. M. Selivanov, V. M. Skrypniuk, O. V. Skrypniuk, M. O. Tepliuk, O. Yu. Todyk, Yu. M. Todyk, O. F. Frytskyi, Yu. O. Frytskyi, V. M. Shapoval, V. O. Shevchuk, S. V. Shevchuk, Yu. S. Shemshuchenko, O. I. Yushchik, O. N. Yarmysh and others.

\section{Retrospective of function in various fields of social sciences}

In modern constitutional law science there is a theoretical connection between the existing concepts of state genesis and the so-called classical concepts of state, state power, constitutional mechanism of state power, which have been elaborated in the theory of law and other specialized studies. A brief overview of the relevant literary sources makes it clear that the relevant legal literature on this issue provides a synthesis 
of positivist and Marxist ideas, reflecting both basic ideas about the structure, attributes and functions, and the types and kinds of state. Generally presented concepts in the theory of the state and law represent a paradigm of understanding state power, based on three sources of its constitution: social and public (sociologism); institutional and legal (normativism and etatism) and moral value (ethical axiologism - ethicism). The problem is the theoretical and cognitive necessity to establish the relation between sociologism, etatism and ethicism in different state scientific concepts.

In order to study and define the system of functions of the constitutional mechanism of state power, it is first and foremost necessary to consider the semantics of this legal category.

The study of scientific literature convincingly shows that the term "function" is multidimensional; it is suitable for characterization of any dynamic structures (Onischenko, 2002). This is due to the specific cognitive tasks of those sciences where it is applied. Like many other concepts in social science, the concept of "function" is not purely a legal or political notion while being used in various fields of knowledge and being characterized by the coverage of properties that are selected depending on the specifics of the field of science.

In the process of development of the theory of functions and the process of systems' functioning in different branches of social sciences, there is a search for new concepts and qualitatively updated models of organization, which require appropriate analysis and synthesis of knowledge, achievements and integration of socio-humanitarian knowledge, use of a wide factual base of relevant specialized legal researches, etc.

For the first time, the concept of "function" was put into use in mathematics (Vynogradov, 1985) and was interpreted as implementation of actions over quantities. The evolution of the concept of "function", namely the basic stages of the formation of the idea of function, coincides with the periodization in mathematics and science in general. Natural and scientific basis of the concept of "function" goes back to antiquity, is developing during the Renaissance, and in the XVII century the concept of function in science is first brought into use in the writings of Des- cartes and Fermat. The term "function" was first presented in scientific meaning by the German mathematician and philosopher G. Leibnitz, who used the term to name various parameters related to the position of a point on a plane; the term was introduced into everyday language by the Swiss mathematician I. Bernoulli (Prokhorov, 1987).

Subsequently, the concept of "function" became part of the conceptual apparatus of many social sciences, physics (Prokhorov, 1983), medicine (Prokhorov, 1996), psychology (Platonov, 1982) and others. Borrowing categorical concepts in a particular scientific field is an objective phenomenon. In addition, the meaning of such a term can be significantly different from the original and have a different content load in a specific field of scientific knowledge.

The term "function" comes from Lat. functio and means realization, execution, accomplishment - a way of doing a thing or an element of the system, aimed at achieving a certain effect (Shynkaruk, 1986). In an explanatory dictionary, the term "function" is defined, firstly, as the work performed by an organ or organism; secondly, as a duty, the scope of activities, the purpose, the role (Lopatina, 1990). Thus, the term "function" means not merely the execution or realization (Kubko, 1997), not only the "internal capacity for certain actions" or "the work of someone, something, the scope of activity of someone, something” (Busel, 2001), but also the fact that this process is always considered in terms of the external manifestation of the qualities of the object under study within a certain system of relations (Skrypniuk, 2005).

In the specialized literature, function means "the external manifestation of the qualities of any object in the system of relations"; "certain processes carried out by the system as a whole"; "the result of any social action and process"; "directions of influence of the system on the reality, which reflects its (system's) essence, role, patterns of development and social purpose"; "the role played by a particular object" (Kartashov, 2009); social purpose ("proper") and practical activities for the implementation of social purpose ("essence") (Hlebov, 1999). However, these opinions are not exhaustive, as other views on the concept of "function" are analyzed in detail in the literature. 
Some researchers define functions as goals and tasks (Hurnei, 1969; Kutsenko, 1972). Thus, these concepts cannot be considered identical, although they are closely related. So, the goal is what you want to accomplish, something you need to conmplete. In philosophy, this concept is defined as "the ideal image of the desired result, which is constructed by consciousness and is a prerequisite for real operations to achieve the intended" (Momdzhian, 1997). In turn, the task needs execution, solution. Goals and tasks determine the presence and existence of certain functions, their specific content.

L. R. Nalyvaiko (2009) points to the ambiguity of the category "function" and emphasizes that it can be applied to any system: social, technical, biological, etc. The structure of any system is determined by its functions. Irrelatively to functions, it is impossible to talk about the expediency and effectiveness of the structure of an object. Change of functions leads to a change in structure that is why the functional method of cognition is always primary compared to the structural method. There is an optimal structure for a certain set of functions, so the effectiveness, for example, of any social organization depends directly on the clarity and accuracy of the detection of its functions.

Considering different views on the meaning of the concept of the category "function", it is possible to conclude that "function" is a kind of "a pattern", "standard", "ideal model" of the system (in this case, the constitutional mechanism of state power), and therefore it should be distinguished, on the one hand, from the goals and tasks that the system faces and, on the other hand, from the real, actual activity of its institutions (competences). However, in practice, systems often deviate from their functions for one reason or another. Therefore, when defining the functions of the constitutional mechanism of state power, it must be assumed that, firstly, the functions are the directions of influence of a certain socially significant phenomenon or circumstance on certain legal relationships, and secondly, the functions are the activity of certain subjects of the constitutional mechanism of the state authorities within the powers specified in the Constitution and laws; thirdly, functions reflect the essence of the phenomenon, its purpose and patterns of development.

\section{Definition of the concept of functions of the constitutional mechanism of state power}

In jurisprudence, the term "functions" is used to refer to various spheres of legal organization and activity (for example, such as "functions of law", "functions of state", "functions of state power", "functions of constitution", "functions of parliament", "functions of the judiciary" etc.). Investigation of the functions of the constitutional mechanism of state power must be carried out through the prism of defining "functions of the state", "functions of state power" and "functions of law", because in many ways there are similarities in their definition, but there are nevertheless some differences.

In our opinion, the theory of functions of the constitutional mechanism of state power should proceed from the social purpose of the state, its tasks and goals, the legislation of Ukraine, and also the experience of practical activity of the state apparatus and the achievement of scientific opinion in the field of constitutional law and a number of theoretical and applied legal sciences.

In ancient times, two functions of the state were distinguished - provision of the common weal and exercising organized coercion. Specific historical circumstances of the development of society determined domination of the particular approach in the political thought (Chyrkin, 1994). It is natural, therefore, that at the stage of development of capitalism, when society had a distinct class structure, when antagonistic class contradictions existed in it, the doctrine of class struggle was formed as the basis of ideas about the state and law. Under such conditions, it was historically justified. But it is unlikely that this doctrine can be the basis for the study and construction of modern state and law, when new conditions in society emerged, in particular:

a) society is devoid of clearly defined classes, and a complex and branched social structure exists;

b) social contradictions are no longer antagonistic, and therefore organized by the state violence against large social groups loses its relevance;

c) the level of material prosperity provides an opportunity for the wider population to live a standard of living consistent with modern ideas about human dignity. 
Thus, such studies require an analysis of historical conditions, trends and dynamics of their development. The modern period of human development is characterized by the fact that its purpose is comprehensive development of a man, provision of conditions for his life, rights and freedoms. Reality is imbued with ideas of humanism, the priority of universal values. All this is reflected in modern most developed countries - legal, democratic, socially oriented.

The state does not fully merge with society, does not dissolve in it, it is an organization that is in a way separated, institutionalized in the form of a mechanism of the state (state system), has its own laws of formation, functioning and development, special needs and interests. Therefore, the study of the characteristics of the state must be carried out both in terms of the unity of the state and society, and their separation. A methodological approach to such an analysis of the concept, essence and purpose of the state is the interpretation of the state as a particular form of organization of society; the form which is its internal organization, the structure of social relations, the means of ordering them and ensuring their smooth existence. And in the external aspect, it unites society in the form of territory, individuals and their associations, state officials and bodies, laws and other legal documents (Kovalenko, 1994).

In understanding the essence, attributes, functions of the state and the mechanism of state power in the legal literature, there are three paradigms: sociologism, normativism (etatism) and axiologism (ethicism).

In the modern domestic legal literature, there are no complete studies of the phenomenon of the mechanism of state power, and the question of the definition and classification of its functions is poorly understood. This state of affairs is conditioned by the formation of a model of Ukrainian constitutionalism and determines the particular relevance of this problem. The theory of the functions of the constitutional mechanism of state power should proceed from the social purpose of the state, its goals and tasks, legislation, as well as the experience of practical activity of the state apparatus and the achievement of scientific opinion in the field of constitutional law and a number of theoretical and applied legal sciences. Actually the system of functions of the state determines the necessity to study the functions of the constitutional mechanism of state power, but if the functions of the state are the directions of influence on public relations, then the functions of the constitutional mechanism of state power are namely the directions of the state functions within the competence of individual institutions that make up the structure of the constitutional mechanism of state power.

V. B. Averianov (2004), relying on the methodology of general systems theory, stated the polysemanticity of the concept of "function", which in Latin means "fulfillment". However, the researcher did not consider such a definition trivial, and we completely support this idea. The researcher considered function as a way of manifesting the activity of the system, stable active relationships in which changes of some objects lead to changes of others, which, according to the researcher, could mean "ability to activity and the activity itself, role, quality, meaning, task, dependence of one value on another, etc. “. V. B. Averianov (2004) thus distinguishes two characteristic dimensions of functions of state power - the potential and the real. A potential dimension of a function refers to the ability to implement a particular activity, whereas a real dimension refers to the direct implementation of that activity.

One of the representatives of social systemology Yu.P. Surmin (2003), who, in his research, uses the concept of function, draws attention to the polysemantic nature of the concept, understanding the function as a direction of the activity of the system and relates to it "firstly, the effect of the system and its response to the environment; secondly, the multiple states of the outputs of the system, therefore, explicit manifestations of its activity; thirdly, in a descriptive approach to a function, it acts as a property of a system that is expanding in dynamics; fourthly, as a process of achieving the goal by the system; fifthly, as concerted between the elements actions in terms of realization of the system as a whole; sixthly, as a trajectory of a system's motion, which can be described by mathematical dependence, by a formula that binds dependent and independent variables of the system".

In his dissertation O. V. Batanov (2011) also states the reasonableness to apply the analysis 
of the state's functions in the context of system-functional approach, which should be supported in the aspect of the fact that conceptual analysis of constitutional and legal phenomena would be incomplete, static without clarifying the functional aspects of the state power. Systematic and structural analysis, while being universal in nature, does not cover all the general scientific methods of the cognition of the state power and the constitutional mechanism, which also require functional characterization, "since the immanent quality of any system along with its origin and development is its functioning”.

Most scientists propose to understand the function of the state not only as a direction, but also as a "aspect of activity". Thus, M. V. Chornoholovkin (1970) combines in the concept of functions both the direction and the "aspect of activity" of the state to solve the historical problems that appear at the basic stages of development. According to M. V. Chornoholovkin (1970), the positive of this definition is that it delimits the ability and possibility of the state to certain activities, which is objectively necessary direction of activity and active implementation of this ability, in other words - parties in practical activity.

This approach, for all its methodological value, has given rise to a new flaw in the scientific understanding of the category of "function of the state". Trying to define the functions of the state through the concept of "ability for activity" is unlikely to be productive, although in this approach, as in all others, there is some rational grain. The fact is that some scientists, such as L. I. Zahainov (1968) and M. V. Chornoholovkin (1970), considered that it is possible to solve the problem of defining the concept of "function of the state" taking into account the dualistic character of its nature: on the one hand, it is the ability for certain activity (potential), and on the other hand it is the realization of this ability (realization of potential). This solution enables to combine in the concept of "function of the state" the potential moment and the real activity of the state. Such dualism, in their view, should be reflected in the definition of this concept. Formulating it, L.I. Zahainov (1968) and M.V. Chornoholovkin (1970) reflect both points, defining the function of the state both as a direction and as an aspect of the state activity.
According to current researchers, this approach raises some serious observations. On the one hand, it is not clear what the fundamental difference between the directions and aspects of the state's activity is, and on the other hand there is a dispute in the legal literature about which of these concepts makes it possible to differentiate the functions of the state from its activity. Thus, approving that the function of the state has a dual nature, M. V. Zhyhulenkov (2002) reflects this point in defining state functions in a different way, treating them as "the ability for activity implemented by the state".

According to V.V. Zatonskyi (2006) such decision does not solve the problem. After all, if we consider the function of its ability for activity (especially the one that is only being realized), the question naturally arises: what to do with the situations when we evaluate the state as weak, inefficient, unable to solve the essential tasks of society's development? Does such a state have no functions? It gives the impression that the ability to act is a qualitative characteristic of the state, but not its function. This may be a condition for effective implementation of the function, but not the function itself.

In modern domestic legal science we can find definitions of the functions of the state as the main (general) and permanent directions (types) of its activities, which are implemented in certain forms, by means of special methods, are of complex (synthesizing), subject-political and objective character, with clearly defined content and its object of influence, they reflect and specify the essence, tasks, social purpose and goals of the state (Bermicheva, 2002).

M. Yo. Baitin (1979) defines the functions of the state as "directions (and parties) of its activity, in which its class essence, official role, tasks, goals, regularities of development are expressed and specified". The author emphasized that this definition of the functions of the state has received the greatest recognition in science. In general, it does not contradict the generally accepted understanding of the functions of the state, although it contains a lot of new things. It draws attention to the understanding of the functions of the state as the directions of its activity, rather than the main directions, what is difficult to agree with. After all, certain phenomena, such as goals, tasks of the state, are also directions of 
its activity, which are "expressed and specified" in its functions. So, as V. F. Pohorilko (1986) rightly considered that the functions of the state are the main directions in all its activities.

Another scientist, M. V. Novikov (2008), in defining the notion of the functions of law, notes that they characterize both the purpose of law and the direction of its influence on social relations; and at the same time considers that the function in its essence is the specification of tasks and the manifestation of the role of law in a certain period.

Given that the state is a social organization of the people living on its territory, united by state power, P. V. Onopenko (2005) also tries to give his own definition of the functions of the state. In his opinion, they are homogeneous, stable directions of the state's activity which purpose is to meet the needs objectively conditioned by the state and the essence of state power.

The scientist S. K. Mohil (2003) proceeds from the conceptual idea that the main tasks and goals of the state at different stages of its development are stipulated by the economic, political, social and other conditions of its existence and determine the main directions of its activity that is the functions of the state. The exercise of the state functions, as the researcher notes, occurs constantly, systematically, throughout the entire existence of the state. In doing so, the functions of the state emerge, are exercised and evolve according to the tasks that should be solved by the state in specific historical conditions.

Rather original is the position of V. M. Temchenko (2003), who believes that the functions of the state should be understood as the historically predetermined basic directions of its activity in ensuring the fundamental rights, freedoms, conditions of fulfillment of the duties of a person and citizen, in which the subject and content of the activity of the state are reflected and specified, its essence and social purpose are revealed.

A. M. Loshchykhin (2010) insists on the social nature of the state, he proposes to define the functions of the state as cardinal, permanent directions and types (aspects) of the state's activity, determined by the objective needs of social development in terms of its internal and external tasks, in which its essence and social purpose are expressed and specified.
L. A. Morozova's (2002) position is also worth paying attention to. She treats the functions of the state as "a special mechanism of state influence on social processes and relations that determine (the mechanism) the main directions and content of its activities in the management of society". She substantiates her position by the fact that, while performing certain functions in certain spheres of society, the state simultaneously, through reforms, various transformations, legal regulation of social relations influences the condition of social processes. Exercising specific functions can stabilize the conditions of social development, creatively influence it, and exacerbate its crisis (Morozova, 2002). We believe that to define the functions of the state as "a special mechanism of state influence on social processes and relations" is not quite correct; it is more peculiar to characterizing the functions of the constitutional mechanism of state power. But despite the debatable character of the inclusion to the concept of the functions of the state mechanism for their implementation, we note that such point of view exists in modern legal science.

N. Pelykh (2005) defines the functions of the state due to the activity of the state apparatus. She thinks them to be the main directions of its activity; they determine the work of the entire state apparatus and each of its separate bodies.

V. Ya. Liubashyts (2002) describes the functions of the state as the main directions of its activity in the management of society, including the mechanism of state influence on the development of social processes in which its essence and social purpose are expressed.

In contrast to the stated positions O. M. Loschykhin (2010) believes that the function of the state is neither the process, nor the activity, it is the basis, the nature of state activity. A strong effective state is rigidly functional, that is, its entire activity is the practical realization of its functions (only its own, state ones and not others). The scientist notes that "the state has never undertaken, does not undertake, cannot and should not undertake full duties for solving all the tasks facing the society and its political system at every specific historical moment, and, of course, be responsible for all functions performed by society and its political system. The state is one of the elements (subjects, constitu- 
ents) of the political system of society, and its functions are an integral part of the functioning of the political system and society as a whole”. Such a statement is highly controversial, since if the state cannot assume the tasks that society faces, then who has to fulfill them and what the state's mission is? But if to treat the functions as an ideal model of the system, then we can say that the state should seek to implement them fully.

Further research also requires a distinction between notions "function" and "functioning". Although the terms are closely related semantically (therefore often used as synonyms), these categories reflect different legal phenomena. The concept of "function" expresses the main directions of influence of a certain phenomenon, impact of the system on social relations, characterizing the social role, realization of certain tasks in accordance with social purpose.

The position expressed by N. M. Onishchenko (2002) can be completely concurred with. She states that "the system of functions is always connected with the system of tasks that are assigned to the investigated phenomenon, and the function is the evolutionary ability of the system to certain activity, whereas functioning is a sign of the activity itself, the process of realization of this ability in a particular environment".

If "function" is a complex concept in the sense that it reflects not only the present but also the future (purpose, task, target), then "functioning" reflects the action of law only in the context of modern conditions, the present time period, unless otherwise specified.

\section{Conclusions}

Summarizing the stated scientific and theoretical positions of scientists, we believe that in order to characterize the analyzed legal phenomenon, we should use an activity approach to understanding the functions. Thus, we propose to define the functions of the constitutional mechanism of state power as the directions of activity of subjects of the constitutional mechanism of state power within the competence determined in the Constitution and laws aimed at achieving the goals and tasks of the state. This particular approach is able to reflect the specifics of the functioning of the constitutional mechanism of state power as a whole.

\section{Bibliography:}

1. Сетров, М. И. (1972). Основы функциональной теории организации. Философский очерк. Ленинград: Наука, 164 с.

2. Афанасьев, В. Г. (1981). Общество: системность, познание и управление. Москва: Политиздат, 432 с.

3. Оніщенко, Н. М. (2002). Правова система: проблеми теорії: монографія. Київ: Ін-т держави і права ім. В.М. Корецького НАН України, 352 с.

4. Виноградов,И.М.(1985). Математическая энциклопедия: в 5 т. Москва: Сов. энцикл., 1977-1985. Т. 5., 623 с

5. Прохоров, Ю.В. (1987). Математический энциклопедический словарь. Москва: Сов. энцикл., 847 с.

6. Прохоров, А. М. (1983). Физический энциклопедический словарь. Москва: Сов. энцикл., 928 с.

7. Покровский, В. И. (1996). Малая медицинская энциклопедия: в 6 т. Москва: Сов. энцикл., 1991-1996. Т. 6: Токсины - Ящур, 544 с.

8. Платонов, К. К. (1982). Система психологии и теория отражения. Москва: Наука, 309 с.

9. Шинкарук, В. І. (1986). Філософський словник. 2-ге вид., перероб. і доп. Київ: Гол. ред. УРЕ, 800 с.

10. Лопатин, В. В., Лопатина, Л. Е. (1990). Малый толковый словарь русского языка. Москва: Русс. яз., 704 с.

11. Кубко, Е. Б. (1997). Введение в теорию государственно-правовой организации социальных систем. Київ ЮрінкомІнтер, 192 с.

12. Бусел, В. Т. (2001). Великий тлумачний словник української мови. Київ; Ірпінь: ВТФ «Перун», 1440 с.

13. Скрипнюк, О. В. (2005). Конституція України та її функції: проблеми теорії та практики реалізації (до 10-ї річниці прийняття Конституції України): монографія. Київ: Академія правових наук України, 168 с

14. Карташов, В. Н. (2009). Функции правовой системы общества: определения и классификации. Вестник Ярославского государственного университета им. П. Г.Демидова: Серия «Гуманитарные науки», 4, С. 29.

15. Глебов, А. П. (1999). Сущностно-субстанциональный и функциональный подход в исследовании государственно-правовых явлений. Проблемы теории государства и права: учеб. пособ. / под. ред. М. Н., Марченко. Москва: Проспект, 504 с

16. Гурней, Б. (1969). Введение в науку управления / вступ. ст. М. И., Пискотин; пер. с франц. Г. С., Яковлев. Москва: Прогресс, 430с

17. Куценко, В.И. (1972). Социальная задача как категория исторического материализма. Киев: Наук. думка, $371 \mathrm{c}$.

18. Момджян, К. Х. (1997). Введение в социальную философию. Учебноепособие. Москва: Высшаяшкола, 448 c. 
19. Наливайко, Л. Р. (2009). Державний лад України: теоретико-правова модель: монографія. Харків : Право, 598 c.

20. Чиркин, В. Е. (1994). Элементы сравнительного государствоведения. Москва: РАН, Ин-т гос-ва и права, $151 \mathrm{c}$.

21. Коваленко, А. И. (1994). Теория государства и права (в вопросах и ответах) : учебник. Москва : [б.и.], 152 с.

22. Авер'янов, В. Б. (2004). Адміністративне право України. Академічний курс: підруч.: у 2-х т.: Т. 1: Загальна частина. Київ: Вид-во «Юрид. думка», 584 с.

23. Сурмин, Ю. П. (2003). Теория систем и системный анализ: учеб. пособ. Киев: МАУП, 368 с.

24. Батанов, О. В. (2011). Муніципальна влада в Україні: конституційно-правові проблеми організації та функціонування: дис. ... докт. юрид. наук: 12.00.02. Київ, 478 с.

25. Черноголовкин, Н. В. (1970). Теория функций социалистического государства. Москва: Юрид. лит., 215 с.

26. Загайнов, Л. И. (1968). Экономические функции советского государства. Москва: Юрид. лит., 263 с.

27. Черноголовкин, Н. В. (1970). Теория функций социалистического государства. Москва: Юрид. лит., 215 с.

28. Жигуленков, М. В. (2002). К вопросу о классификации функций государства. Право и политика, 8, С. 16-20.

29. Затонский, В. А. (2006). Эффективная государственность: монография / под ред. А. В., Малько. Москва: Юристь, 286 с.

30. Бермічева, О. В. (2002). Соціальна функція держави в Україні: автореф. дис.... канд. юрид. наук: 12.00.01. Харків, 18 с.

31. Байтин, М. И. (1979). Сущность и основные функции социалистического государства. Саратов: Изд-во Сарат. ун-та, 301 с.

32. Погорелко, В.Ф. (1986). Местные Советы в механизме осуществления функций советского общенародного государства: монография. Киев: Наукова думка, 234 c.

33. Новиков, М. В. (2008). Понятие функций права как отражение его сущности на различных этапах развития общества. Вестник Владимирского юридического института, 2, С. 183.

34. Онопенко, П. В. (2005). Правоохоронні функції української держави: зміст і реалізація: автореф. дис. ... канд. юрид. наук: 12.00.01. Київ, 16 с.

35. Могил, С. К. (2003). Сучасна держава в екстремальних ситуаціях: нормативи, органи, функції: автореф. дис. ... канд. юрид. наук: 12.00.01. Одеса, 19 с.

36. Темченко, В. М. (2003). Функції держави із забезпечення прав людини у ринковій економіці. Право України, 5, С. 47-51.
37. Лощихін, О.М. (2010). Теоретико-правові характеристики економічної функції сучасної держави: дис. ... докт. юрид. наук: 12.00.01. Київ, 453 с

38. Морозова, Л. А. (2002). Теория государства и права: учебник. Москва: Юристь, 414 с.

39. Морозова, Л. А. (1993). Функции российского государства на современном этапе. Государство и право, 6, С. 98-108.

40. Пелих, Н. (2005). Функції української держави. Підприємництво, господарство і право, 1, С. 3-6.

41. Любашиц, В. Я., Мордовцев, А. Ю., Тимошенко, И. В. (2002). Теория государства и права: учеб. пос. Ростов н/Д: Изд. центр «МарТ», 512 с.

42. Лощихін, О.М. (2010). Теоретико-правові характеристики економічної функції сучасної держави: дис. ... докт. юрид. наук: 12.00.01. Київ, 453 с.

43. Оніщенко, Н. М. (2002). Правова система:проблемитеорії: монографія.Київ: Ін - т держави і права ім. В.М. Корецького НАН України, 352 с.

\section{References}

1. Setrov, M. I. (1972). Osnovy funktsional'noy teorii organizatsii. Filosofskiy ocherk [Fundamentals of a functional theory of organization. Philosophical essay]. Leningrad: Nauka. [in Russian].

2. Afanas'yev, V. G. (1981). Obshchestvo: sistemnost' poznaniye i upravleniye [Society: systematic, cognition and management]. Moscow: Politizdat. [in Russian].

3. Onishchenko, N. M. (2002). Pravova systema: problem teoriyi: monohrafiya [Legal system: problems of theory: monograph]. Kiev: In-t derzhavy i pravaim. V.M. Korets'koho NAN Ukrayiny. [in Ukrainian].

4. Vinogradov, I. M. (1985). Matematicheskay entsiklopediya: $v 5$ tomakh [Mathematical Encyclopedia: in 5 volumes]. Moscow: Sovetskaya entsiklopediya. Volume 5. [in Russian].

5. Prokhorov, Yu. V. (1987). Matematicheskiy entsiklopedicheskiy slovar' [Mathematical Encyclopedic Dictionary]. Moscow: Sovetskaya entsiklopediya. [in Russian].

6. Prokhorov, A. M. (1983). Fizicheskiy entsiklopedicheskiy slovar' [Physical Encyclopedic Dictionary]. Moscow: Sovetskaya entsiklopediya. [in Russian].

7. Pokrovskiy, V. I. (1996). Malaya meditsinskay aentsiklopediya: $v 6$ tomakh [Small medical encyclopedia: in 6 volumes]. Moscow: Sovetskaya entsiklopediya. [in Russian].

8. Platonov, K. K. (1982). Sistema psikhologii i teoriya otrazheniya [Psychology system and theory of reflection]. Moscow: Nauka. [in Russian].

9. Shynkaruk, V.I. (1986). Filosofs'kyy slovnyk. 2-he vyd., pereroblene i dopovnene [Philosophical Dictionary. 
2nd ed., Revised and Supplemented]. Kiev: Holovna redaktsiya URE. [in Ukrainian].

10. Lopatin, V. V., Lopatina, L. Ye. (1990). Malyy tolkovyy slovar' russkogo yazyka [Small explanatory dictionary of the Russian language]. Moscow: Russkiy yazyk. [in Russian].

11. Kubko, Ye. B. (1997). Vvedeniye $v$ teoriyu gosudarstvenno-pravovoy organizatsii sotsial'nykh system [Introduction to the theory of state-legal organization of social systems]. Kiev: Yurínkomínter. [in Russian].

12. Busel, V. T. (2001). Velykyy tlumachnyy slovnyk ukrayins'koyi movy [Large Interpretative Dictionary of the Ukrainian Language]. Kiev, Irpin': VTFPerun, [in Ukrainian].

13. Skrypniuk, O. V. (2005). Konstytutsiya Ukrayiny ta yiyi funktsiyi: problem teoriyi ta praktyky realizatsiyi (do 10-yi richnytsi pryynyattya Konstytutsiyi Ukrayiny): monohrafiya [Constitution of Ukraine and its functions: problems of theory and practice of implementation (to the 10th anniversary of the adoption of the Constitution of Ukraine): monograph]. Kiev: Akademiya pravovykh nauk Ukrainy. [in Ukrainian].

14. Kartashov, V. N. (2009). Funktsii pravovoy sistemy obshchestva: opredeleniya i klassifikatsii [The functions of the legal system of society: definitions and classifications]. Vestnik Yaroslavskogo gosudarstvennogo universiteta imeni P. G. Demidova: Seriya Gumanitarnye nauki, 4, [in Russian].

15. Glebov, A. P. (1999). Sushchnostno-substantsional'nyy i funktsional'nyy podkhod $v$ issledovanii gosudarstvenno-pravovykh yavleniy [Substantive and functional approach in the study of state-legal phenomena] / pod red. M. N. Marchenko. Moskva: Prospekt. [in Russian].

16. Gurney, B. (1969). Vvedeniye v naukuupravleniya [Introduction to the science of management]. Moscow: Progress. [in Russian].

17. Kutsenko, V. I. (1972). Sotsial'naya zadacha kak kategoriya istoricheskogo materializma [The social task as a category of historical materialism]. Kiev: Naukova dumka. [in Russian].

18. Momdzhian, K. K. (1997). Vvedeniye v sotsial'nuyu filosofiyu. Uchebnoye posobiye [Introduction to social philosophy. Tutorial]. Moscow: Vysshayashkola. [in Russian].

19. Nalyvaiko, L. R. (2009). Derzhavnyy lad Ukrayiny: teoretyko-pravova model': monohrafiya [State system of Ukraine: theoretical and legal model: monograph]. Kharkiv: Pravo. [in Ukrainian]

20. Chirkin, V. Ye. (1994). Elementy sravnitel'nogo gosudarstvovedeniya [Elements of comparative state sci- ence]. Moscow: RAN, Institut gosudarstva i prava. [in Russian].

21. Kovalenko, A. I. (1994). Teoriya gosudarstva i prava (v voprosakh i otvetakh): uchebnik [The theory of state and law (in questions and answers): a textbook]. Moscow (without a publishing house). [in Russian].

22. Averianov, V. B. (2004). Administratyvne pravo Ukrayiny. Akademichnyy kurs: pidruch.: u 2-kh tomakh: Tom 1: Zahal'na chastyna [Administrative law of Ukraine. Academic course: textbook: in 2 volumes: Volume 1] Kiev: Yurydychna dumka. [in Ukrainian].

23. Surmin, Yu. P. (2003). Teoriya sistem i sistemnyy analiz: uchebnoye posobiye [Theory of systems and systems analysis: a training manual]. Kiev: MAUP. [in Russian].

24. Batanov, O. V. (2011). Munitsypal'na vlada v Ukrayini: konstytutsiyno-pravovi problem orhanizatsiyi ta funktsionuvannya [Municipal Government in Ukraine: Constitutional and Legal Problems of Organization and Functioning]. Disertatsiya doktora yurydychnykh nauk: 12.00.02 [Dr. Sc. thesis]. Kiev. [in Ukrainian].

25. Chernogolovkin, N. V. (1970). Teoriya funktsiy sotsialisticheskogo gosudarstva [The theory of the functions of a socialist state]. Moscow: Yuridicheskaya literatura. [in Russian]

26. Zagaynov, L. I. (1968). Ekonomicheskiye funktsii sovetskogo gosudarstva [The economic functions of the Soviet state]. Moscow: Yuridicheskaya literatura. [in Russian]

27. Chernogolovkin, N. V. (1970). Teoriya funktsiy sotsialisticheskogo gosudarstva [The theory of the functions of a socialist state]. Moscow: Yuridicheskaya literatura. [in Russian]

28. Zhihulenkov, M. V. (2002). K voprosu o klassifikatsii funktsiy gosudarstva [On the classification of state functions]. Pravo i polityka, 8, pp. 16-20. [in Ukrainian]

29. Zatonskiy, V.A. (2006). Effektivnaya gosudarstvennost' monografiya [Effective Statehood: monograph]. Moscow: Yurist. [in Russian]

30. Bermicheva, 0. V. (2002). Sotsial'na funktsiya derzhavy $v$ Ukrayini [The social function of the state in Ukraine]. Avtoreferat disertatsiyi kandidata yurydychnykh nauk: 12.00.01 [Ph. D. thesis]. Kharkiv. [in Ukrainian].

31. Baytin, M. I. (1979). Sushchnost' i osnovnyye funktsii sotsialisticheskogo gosudarstva [The essence and basic functions of a socialist state]. Saratov: Izdatel'stvo Saratovskogo universitetata. [in Russian]

32. Pogorelko, V.F. (1986). Mestnyye Sovety v mekhanizme osushchestvleniya funktsiy sovetskogo obshchenarodnogo gosudarstva: monografiya [Local Councils in the mechanism for the implementation of the functions of the Soviet nation-wide state: monograph] Kiev: Naukova dumka. [in Russian]. 
33. Novikov, M. V. (2008). Ponyatiye funktsiy prava kak otrazheniye yego sushchnosti na razlichnykh etapakh razvitiya obshchestva [The concept of the functions of law as a reflection of its essence at various stages of development of society]. Vestnik Vladimirskogo yuridicheskogo instituta, 2, [in Russian].

34. Onopenko, P. V. (2005). Pravookhoronni funktsiyi ukrayins'koyi derzhavy: zmist i realizatsiya [Law enforcement functions of the Ukrainian state: content and implementation]. Avtoreferat disertatsiyi kandidata yurydychnykh nauk: 12.00.01 [PhD thesis]. Kiev. [in Ukrainian].

35. Mohyl, S. K. (2003). Suchasna derzhava v ekstremal'nykh sytuatsiyakh: normatyvy, orhany, funktsiyi [The modern state in extreme situations: standards, bodies, functions]. Avtoreferat disertatsiyi kandidata yurydychnykh nauk: 12.00.01 [PhD thesis]. Odessa. [in Ukrainian].

36. Temchenko, V. M. (2003). Funktsiyi derzhavy iz zabezpechennya prav liudyny u rynkovii ekonomitsi [The functions of the state to ensure human rights in a market economy]. Pravo Ukraiiny, 5, pp. 47-51. [in Ukrainian].

37. Loshchykhin, 0. M. (2010). Teoretyko-pravovi kharakterystyky ekonomichnoyi funktsiyi suchasnoyi derzhavy [Theoretical and legal characteristics of the economic function of the modern state. Disertatsiya doktora yurydychnykh nauk: 12.00 .01 [Dr. Sc. thesis]. Kiev. [in Ukrainian].

38. Morozova, L. A. (2002). Teoriya gosudarstva I prava: uchebnik [Theory of state and law: a text book]. Moscow: Yurist. [in Russian].

39. Morozova, L. A. (1993). Funktsii rossiyskogo gosudarstva na sovremennom etape [The functions of the Russian state at the present stage]. Gosudarstvo i pravo, 6, pp. 98-108. [in Russian].

40. Pelykh, N. (2005). Funktsiyi ukrayins'koyi derzhavy [Functions of the Ukrainian state]. Pidpryyemnytstvo, hospodarstvo i pravo, 1, pp. 3-6. [in Ukrainian].

41. Lyubashits, V. Ya., Mordovtsev, A. Yu., Timoshenko, I. V. (2002). Teoriya gosudarstva i prava: uchebnoye posobiye [Theory of state and law: a training manual]. Rostov-on-Don: Izdatel'skiy tsentr «MarT» [in Russian].

42. Loshchykhin, 0. M. (2010). Teoretyko-pravovi kharakterystyky ekonomichnoyi funktsiyi suchasnoyi derzhavy [Theoretical and legal characteristics of the economic function of the modern state]. Disertatsiya doktora yurydychnykh nauk: 12.00.01 [Dr. Sc. thesis] Kiev. 453 s. [in Ukrainian].

43. Onishchenko, N. M. (2002). Pravova systema: problem teorii: monohrafiya [Legal system: problems of theory: monograph]. Kiev: Instytut derzhavy i prava imeni V. M. Korets'koho NAN Ukraiiny. [in Ukrainian].

\title{
ЗАГАЛЬНОНАУКОВІ ПІДХОДИ ДО ВИЗНАЧЕННЯ ФУНКЦІЙ КОНСТИТУЦІЙНОГО МЕХАНІЗМУ ДЕРЖАВНОЇ ВЛАДИ
}

\author{
Володимир Шатіло, \\ завідувач кафедри права Київського національного лінгвістичного університету \\ доктор юридичних наук, доцент, \\ Заслужений юрист України \\ Orcid.org/0000-0003-3274-4744 \\ vash13@ukr.net
}

\begin{abstract}
Анотація
Метою даної роботи є визначення поняття функцій конституційного механізму державної влади через дослідження доктринальних позицій функції у різних галузях суспільних наук.

Методологію дослідження функцій конституційного механізму державної влади складають методи пізнання, виявлені та розроблені філософією, історією, соціологією, теорією права і держави, галузевими юридичними науками та апробовані юридичною практикою. Так, роль історичного методу у дослідженні функцій конституиійного механізму державної влади, окрім з'ясування природи виникнення і розвитку, полягає у забезпеченні систематичного вивчення еволюції даної категорії. Семантичний метод було застосовано для з'ясування змісту терміну "функція», її наукового та практичного значення, можливості застосування в конституційному праві для позначення таких правових категорій як «конституційний механізм державної влади».
\end{abstract}


Метод порівняльного аналізу застосовувався для розкриття загального в таких поняттях як «функції», «цілі» та «завдання».

Результати дослідження показують, що функцією є своєрідний «взірець», «еталон», «ідеальна модель» роботи системи, зокрема конституційного механізму державної влади, а отже, ії необхідно, з одного боку, відрізняти від цілей і завдань, які постають перед системою, а з іншого - від реальної, фактичної діяльності ії інститутів (компетенціі). При визначенні функцій конституційного механізму державної влади слід виходити з того, що, по-перше, функціі - це напрями впливу певного соціально значущого явища чи обставини на певні правовідносини, по-друге, функції - це діяльність окремих субєєктів конституційного механізму державноі влади в межах повноважень, визначених у Конституції та законах; по-третє, функції відображають сутність явища, його призначення та закономірності розвитку. Теорія функцій конституційного механізму державноі влади має виходити з соціального призначення держави, їі завдань та иілей, законодавства України, а також враховувати досвід практичної діяльності державного апарату та досягнення наукової думки у галузі конституційного права та низки теоретичних та прикладних юридичних наук. Саме система функцій держави детермінує необхідність дослідження функцій конституційного механізму державної влади, але якщо функції держави є напрямами впливу на суспільні відносини, то функції конституційного механізму державної влади $\epsilon$ фактично напрямами реалізації функцій держави в межах компетенції окремих інститутів, що складають структуру конституційного механізму державної влади.

На підставі даного дослідження, автор доходить до висновків, що функції конституційного механізму державної влади визначати як напрями діяльності субєктів конституційного механізму державної влади в межах компетенції визначеної в Конституції та законах, що спрямовані на досягнення цілей і завдань держави.

Ключові слова: функція; механізм державної влади; функції держави; цілі; завдання; діяльність держави. 